УДК 346.1

DOI https://doi.org/10.32849/2663-5313/2020.1.08

\title{
Олександр Ковалишин,
}

канд. юрид. наук,

доцент кафедри судочинства

Прикарпатського національного університету імені Василя Стефаника

\section{ПРАВОВI ЗАПОЗИЧЕННЯ: РRО ЕT CONTRA}

Запозичення в корпоративному праві відіграють вагому роль, зважаючи на глобалізачійні проиеси, які відбуваються у світі. Практика правових запозичень останніми роками стала значно ширшою. Це стосується всіх країн без жодних винятків. Міжнародне право є одним із найпотужніших джерел таких взаємовпливів. Присутність правових запозичень у корпоративному праві України відзначається рядом українських вчених. Проте грунтовний їх аналіз не проводився.

Аналіз правових запозичень важливий не лише в аспекті з'ясування співвідношення з прочесом гармонізачії, зближення та уніфікації права, можливості застосування стандартизованих правових норм, правових конструкиій, вирішення проблем, які виникають у зв'язку з иим. Проблематика правових запозичень значно ширша та має глибше теоретико-методологічне значення. Визнання існування правових запозичень ставить під сумнів одну із засад теорії права про те, що виключно держава визначає зміст права, а право в об'єктивному розумінні завжди є продуктом автономного розвитку всередині держави.

У статті автор аналізує точки зору як прихильників кониепиї̈ правових запозичень, так $і$ скептиків. Автором відзначається, що сприйняття конщепиї правових запозичень серед ї̈ прихильників суттєво різниться - від кониепиї правових запозичень як вільно трансплантабельних правових норм та інститутів незалежно від регіональних умов (Аллан Ватсон, Дж. Самуель) до визнання правових запозичень з урахуванням сочіально-економічних умов держави, якою запозичується правова норма, інститут чи доктрина (Отто Кан Фрейнд, Е. Оруку, Матіас Сімз та ін.).

Скептицизм більшості критиків ідеї правових запозичень зводиться до неможливості ідентично20 тлумачення через різний рівень правової свідомості, відмінності у правовому мисленні, неможливість досягнення ідентичного впливу на суспільні відносини у зв'язку з різницею соиіального та економічного розвитку в державах.

Автор підсумовує, що правові запозичення важливі тим, що дозволяють удосконалити корпоративне право України не лише на основі стандартів права товариств $C C$, а й з урахуванням досвіду застосування іноземних правових інститутів, що довели свою ефективність як у країні походження, так і зай межами.

Ключові слова: правове запозичення, правовий трансплантат, рецепція, уніфікація, корпоративне право, порівняльне правознавство.

Постановка проблеми. Сучасний етап розвитку права характеризується уніфікацією правового регулювання в більшості галузей права. Особливо відповідні процеси відчутні у сфері господарського (комерційного) та корпоративного права.

У науці господарського та корпоративного права, та й загалом у теорії права, використовуються в основному терміни «уніфікація», «гармонізація», «рецепція», «наближення» та ін. Але всі вони позначають процес змін у праві, а не саму правову конструкцію, правовий інститут чи правову норму, яка запозичується (реципіюється). Тому правова наука, зокрема наука корпоративного права, потребує детального дослідження такого поняття, яке позначало б саме те одиничне правило поведінки суб’єкта господарських правовідносин чи сукупність таких правових норм або цілий правовий інститут. Саме таким терміном, як видається, $€$ «правове запозичення», в правовій науці західних країн він більш відомий під назвою «правовий трансплантат».

Рецепцію і запозичення не можна ототожнювати, бо під рецепцією, як правило, зазвичай розуміють сприйняття цілої низки правових інститутів на рівні галузі права (як-от рецепція римського приватного права, рецепція кодексу Наполеона, рецепція корпоративного права Німеччини). Термін «рецепція» означає специфічний підвид синхронної наступності в праві, особливість якого полягає у глобальному запозиченні елементів іноземного права: його сутності, системи або її структурних основних елементів (галузі, інститути) [1, с. 128]. 
Однак у сучасних умовах все частіше має місце хаотичне запозичення окремих норм, конструкцій. Крім того, почастішало прийняття законів на основі модельних законів міжнародних організацій. Усі ці явища складно назвати рецепцією, гармонізацією чи наближенням. Проте вони є і значною мірою визначають вектор розвитку цілих галузей права.

Аналіз останніх досліджень і публікацій. Проблематику правових запозичень вивчали ряд вітчизняних та іноземних науковців у сфері теорії права та порівняльного правознавства. Основоположниками ідеї правових запозичень були Алан Ватсон та Отто Кан Фрейд. Їхня концепція надалі отримала розвиток у працях таких вчених, як Матіас Сімс, Євгенія Куржинскі-Зінгер, Елеонора Кашін, Дж. Міллер, Уве Кішель та ін.

Серед українських вчених варто виділити А. Сапарову, О. О. Оборотова, Л. В. Аврааменка, О. В. Ткаченка, в наукових працях яких досліджується співвідношення наступності та запозичень у праві України, їхнього місця в теорії права. Але окремого дослідження, яке було б присвячено питанням правової природи правових запозичень, не проводилось.

Мета дослідження полягає в аналізі поглядів учених на явище правових запозичень в теорії права.

Виклад основного матеріалу. Дискусія навколо правових трансплантатів розгорнулася в середині 1970-х років між Отто Кан Фрейнд [2] та Аланом Ватсоном [3], останній з яких був апологетом ідеї правових трансплантатів та визначав правовий трансплантат як рушійну силу змін та розвитку систем права окремих держав. Майже одночасно 3 Аланом Ватсоном методологічні аспекти правових трансплантатів описані в праці Родольфо Сакко [4]. Хоча, як зазначається в «Оксфордському посібнику з корпоративного права», передумови для формулювання такого терміна Аланом Ватсоном виникли ще значно раніше.

Після конференції «Рецепція іноземного права в Туреччині», проведеної Міжнародною асоціацією юридичної науки, Міжнародна Академія порівняльного права (найвпливовіша світова організація у сфері порівняльного права) присвятила окрему сесію Конгресу 1970-го року «Глобальна рецепція іноземного права» [5, с. 632], де порушувалися питання впливу правових моделей, правових конструкцій окремих країн на інші. А вже у 2010-му році XVIII Конгрес порівняльного права носив відповідну назву «Legal Culture and Legal
Trasplants», що свідчить про поступове визнання на міжнародному науковому рівні відповідної правової концепції.

Метафора «правова трансплантація» 3 їі яскравим образом, взятим зі світу анатомії та хірургії, прижилася у зв’язку з тим, що вдало передає поширене сприйняття права як квазіорганічної речовини, а також загальне уявлення про складну та чутливу природу права, можливість прийняття законів та правових інститутів, які розвивалися в одному конкретному правовому та інституційному середовищі, але працюють поза їх природним «середовищем існування» [6, с. 112].

На думку Аллана Ватсона, правовий трансплантат «е основним методом дослідження правового розвитку», оскільки саме «причинно-наслідкові відношення між трансплантатами і їх іноземними попередниками $€$ фундаментальними для вивчення міграції правових ідей». Вчений зазначає, що правові трансплантати забезпечують більшість правових змін тому, що «право не грунтується на національних умовах, i, відповідно, правові норми можуть розглядатися незалежно від будь-якого конкретного суспільства», а отже, існує можливість безперешкодного перенесення юридичних норм з однієї правової системи в іншу [7, с. 121].

Дж. Самуель зазначає, що основою ідеї правової трансплантації є ствердження можливості редукції права до ряду лінгвістичних речень, завдяки якій гармонізація чи уніфікація права стає відносно простим завданням - «це лише справа введення цих речень у лінію» [8, с. 226-227].

Більш помірковано висловлюється Отто Кан Фрейнд, підкреслюючи необхідність урахування соціально-політичного змісту (конституційного та політичного правопорядку) в країні-донорі та державі-реципієнті, особливо в тих сферах, на які чиниться тиск з боку впливових груп всередині даної держави [2, с. 20].

Більшість прихильників ідеї правових запозичень відзначають, що останні $€$ неодмінним елементом глобалізації в праві. Зокрема, на думку Джеймса Гундерсона, в часи швидких змін часто немає можливості створювати власне «органічне» законодавство і немає сенсу «винаходити колесо» [9, с. 358]. Більш ефективні правові теорії і рішення поширюються по всьому світі з нульовими операційними витратами: в сучасному світі ефективні правові рішення зберігаються, тоді як неефективні зникають. Тобто якщо операційні витрати дорівнюють нулю, тоді право розглядається як «вільно трансплантабельне (здатне до вільного переміщення) і таке, що природно розвивається 
в напрямі найбільш ефективних норм» $[10$, c. 121$]$

Матіас Сімз наголошує на тому, що існування правових трансплантатів обгрунтоване насамперед запитами провідних держав світу та міжнародних фінансових структур [11, с. 104] у пошуку універсального механізму вибіркового перенесення правових норм з однієї юрисдикції в іншу. А ідея існування конкуруючих ринків постачання права «€ не лише застосуванням концепту правових трансплантантів, але і його теоретичним обгрунтуванням» [12, с. 162].

Е. Оруку, аналізуючи концепт правових запозичень, відзначає, що «розгляд права як мобільної сили, що змінюється, експортуючи і імпортуючи інститути означає, що право сприймається так само як і будь-яка технологія, продукт людського досвіду, i, відповідно, як таке, що допускає своє переміщення» [13, с. 5]. А порівняльне правознавство, на думку вченого, з одного боку, вивчає невдачі та слабкості трансплантації як засобу правової реформи і модернізації, ігноруючи соціально-культурне розмаїття (підкреслюючи невдалі приклади, особливо пов'язані з колоніальним досвідом), а з іншого боку, порівняльні дослідження права показують, що юридичні трансплантації є кращим способом модернізації і не викликають нестабільності в наявній правовій чи соціально-культурній сферах (за яких успішність трансплантацій можлива та реальна, коли одержувач, за рахунок власних творчих зусиль 3 модернізації, використовує імпорт у своїх власних спільних інтересах, не відчужуючи соціальну культуру) [14].

Загалом же натепер концепт правових трансплантатів висвітлюється практично в кожній міжнародній енциклопедії чи монографії з проблем порівняльного правознавства $[15 ; 16 ; 17]$.

Явище правових запозичень не залишилося поза увагою й вітчизняної юридичної науки. А. Сапарова, позитивно ставлячись до ідеї правових запозичень, відзначає, що правові запозичення, якщо їх розуміти у світлі інтегративного праворозуміння, кидають виклик твердженню, що виключно влада суверена визначає правові зміни. У межах дослідження правових запозичень релевантним є питання, яке підриває засадниче припущення правового позитивізму: якою мірою державна влада дійсно визначає зміст права [18, c. 250-251].

На думку О. О. Оборотова, запозичення принципів, норм і цінностей західноєвропейської цивілізації ігнорує правову культуру і правовий менталітет народу України, його правову спадщину [19, с. 18]. Вчений відзна- чає, що на тлі непродуманого запозичення західних державних і правових інститутів, що призводять до дестабілізації державного життя й посилення правового нігілізму, існує можливість здійснення реформ на основі євразійської правової моделі й відповідної ій гарантійної державності $[19$, с. 20]. I хоча автором не підтримується системне запозичення з права країн Західної Свропи, однак разом із тим наголошується на необхідності приєднання до євразійської правової моделі, що неодмінно також пов'язано із запозиченням певних ідеології, принципів, окремих правових інститутів.

Слід зазначити, що сприйняття концепції правових запозичень серед її прихильників суттєво різниться - від концепції правових запозичень як вільно трансплантабельних правових норм та інститутів незалежно від регіональних умов (Аллан Ватсон, Дж. Самуель) до визнання правових запозичень з урахуванням соціально-економічних умов держави, якою запозичується правова норма, інститут чи доктрина (Отто Кан Фрейнд, Е. Оруку, Матіас Сімз та ін.).

Критики ідеї правових запозичень цитують Монтеск'є, який свого часу зазначив, що «політичні та цивільні закони кожного народу настільки пристосовані до людей, для яких вони створені, щоб це було би чистим збігом (un grand hazard), якщо б закони одного народу могли би задовольнити потреби іншого» [20 с. 41].

Коли в науковій літературі йдеться про цитування сучасних критиків ідеї «правових запозичень», то насамперед згадують П'єра Леграна, на переконання якого необхідним $€$ перенесення не лише форми, а й значення норми, що видається майже неможливим [21, с. 49]. Вчений наголошуе на неможливості «правових трансплантатів», виходячи з того, що правова норма, перенесена з однієї юрисдикції в іншу, є лише «формальною сукупністю слів, позбавлених свого первинного змісту» [22, с. 120]. «Для того, щоб перенести одне слово без спотворення, необхідно перенести всю мову, що його оточує. Для того, щоб перевести текст без зміни його значення - необхідно перенести його аудиторію» [23, с. 42]. На підтвердження даної тези в юридичній літературі часто згадуються результати рецепції цивільного кодексу Німеччини Японією на поч. XX ст., в якій чимало правових конструкцій отримали зовсім іншу інтерпретацію. Або ж рецепція швейцарського кодексу зобов'язань у Туреччині [24, с. 24].

Дещо іншу позицію висловив Гюнтер Тойнбнер, зазначаючи, що правові норми та інститути, наче віддзеркалення сус- 
пільства, пов'язані $з$ ним різноманітними зв'язками особливим чином. Тому просте перенесення неможливе. Але перенесені норми виступають правовими подразниками, які спричинюють зміни у відповідних видах суспільних відносин [25, с. 17]. Таким чином, вищезгадані критики концепції правових запозичень акцентували увагу насамперед на різній правовій природі правових трансплантатів.

Частиною вчених можливість та успішність правового запозичення піддається сумніву, виходячи з того, що соціальноекономічні відносини в країні запозичення і державі, яка запозичує, завжди різняться [26, с. 473]. Критично ставиться до ідеї правової трансплантації К. Осакве, зазначаючи, що таке припущення є мовною ілюзією - припущенням акустичної подібності між термінами, вживаними в різних правових системах; уникнення цієї мовної ілюзії передбачає усвідомлення, що термінологічна подібність окремих понять і інститутів «не означає повного збігу їх змісту; в кожному конкретному випадку істинний зміст будьякого поняття розкривається в контексті своєрідної правової системи» [27, с. 61].

Українські вчені насамперед наголошують на необхідності врахування місцевих регіональних умов. С. Є. Чебуранова акцентує увагу на тому, що кожна держава має свої національно-історичні особливості і традиції, що не може не вплинути на зміст і форму різноманітних правових інститутів. Тільки створені з урахуванням національної культурної специфіки, національного історичного досвіду, існуючої моделі організації державної влади, такі форми можуть бути міцними і стабільними» [28, с. 18].

На думку О. В. Ткаченко, «правові трансплантати» виявляються неможливими, оскільки кожне право залишається виразом мови, культури і традиції, які покликали його до життя. Завжди дієвим є фактор доместикації [29, с. 39]. М. А. Даммірлі відзначає, що запозичення не залишається у первісному вигляді, а трансформується відповідно до умов життя народу, який запозичує, які, своєю чергу, ніколи не бувають повністю тотожними [30, с. 70-71], концепт правової трансплантації виявляється нездатним охопити всю складність феномену експорту й імпорту права [31, с. 129].

Беручи до уваги погляди згаданих вище як прихильників, так і противників концепції «правових запозичень», хотілося б відзначити таке. Процес творення будь-якої галузі права відбувається завдяки внутрішнім чинникам, таким як соціально-економічний устрій, суспільна свідомість, рівень правової культури тощо. Але не слід залишати поза увагою і зовнішні впливи на процес формування національного права. Складно навести приклад держави, право якої розвивалось б абсолютно автономно, незалежно від правових систем інших держав. У кожній системі права постійно присутній певний вплив ззовні. Останній у праві, серед іншого, проявляється у правових запозиченнях.

Сприймаючи ідею Монтеск'є про індивідуальність та неповторність кожної системи права, хотілося б зазначити, що економікоправові, політичні та соціально-культурні реалії сьогодення дещо інші, ніж ті, які були декілька століть тому. В умовах сучасності, 3 розвитком технологій телекомунікації та зближення моделей поведінки людей, моделей управління суспільством, відмінності систем права різних держав поступово нівелюються. Будь-якій державі, для того щоб залишатися конкурентоспроможною на світовому та регіональному ринках, необхідно в тому числі адаптувати внутрішне правове поле так, щоб воно якомога краще забезпечувало інтереси суб'єктів господарювання. Як слушно зауважує Єва Ляйн, «те, що, можливо, було виправданим в епоху Монтеск'є, є вже неактуальним в епоху глобалізації та створення єдиного європейського ринку» [32, с. 13].

Критика П. Леграна більшою мірою стосується не самих правових трансплантатів, а того факту, що будь-яка правова норма, як би точно вона не була відображена в законодавстві країни-реципієнта, отримує зовсім іншу інтерпретацію, виходячи 3 особливостей правової культури. Тобто П. Легран заперечує не саму можливість існування правового запозичення як процес перенесення норми права з однієї країни в іншу, а саме можливості схожої інтерпретації, а відповідно, поведінки суб'єктів, яких воно стосується.

Скептицизм більшості критиків ідеї правових запозичень зводиться до неможливості ідентичного тлумачення через різний рівень правової свідомості, відмінності у правовому мисленні, неможливість досягнення ідентичного впливу на суспільні відносини у зв'язку з різницею соціального та економічного розвитку в державах. Таким чином, як видається, науковою спільнотою заперечується не сам факт існування певних ефективних правових конструкцій, які запозичуються з однієї системи права в іншу, а можливість досягнення ідентичного впливу на суспільні правовідносини. I з цим варто погодитися. Правова свідомість, соціально-економічні умови, особливості господарських зв'язків, динаміка розвитку економіки в Україні 
відмінна від будь-якої іншої держави. Але це не може слугувати причиною відмови від урахування ефективних правових конструкцій.

\section{Висновки}

Правові запозичення важливі тим, що дозволяють удосконалити корпоративне право України не лише на основі стандартів права товариств $€ \mathrm{C}$, а й з урахуванням досвіду застосування іноземних правових інститутів, що довели свою ефективність як у країні походження, так і за її межами.

При цьому хотілося б наголосити, що дослідження змін у праві крізь призму правових запозичень нагально необхідне, оскільки ті процеси, які відбуваються в праві, не можна описати виключно через уніфікацію, гармонізацію, наближення чи рецепцію.

\section{Список використаних джерел:}

1. Авраменко Л. В. Наступність (сприйняття та запозичення) в праві України: теоретичні аспекти. Вісник Харківського нащіонального університету внутрішніх справ. 2000. № 10. С. 125-130.

2. Kahn-Freund Otto, On Uses and Misuses of Comparative Law, Modern Law Review, 1974. Vol. 37. P. 1-27.

3. Watson Alan, Legal Transplants and Law Reform, The Law Quarterly Review, 1976. Vol. 92. P. 79-84.

4. Rodolfo Sacco, Les buts et les methodes de la comparaison du droit, in Rapports nationaux italiens au IX Congres international de droit compare, Teheran, 1974. P. 127-131.

5. Reimann Mathias, Zimmermannn Reinhard, The Oxford Handbook of Comparative Law, 2019. P. 632.

6. Antonina Bakardjieva Engelbrekt. Legal and Economic Discourses on Legal Transplants: Lost in Translation? Stockholm University. P. 112-140.

7. Watson A. Legal Transplants : An Approach to Comparative Law / A. Watson. Edinburgh : Scottish Academic Press, 1974

8. Samuel G. Taking method seriously (part two) / The Journal of Comparative Law. 2007. Vol. II. Issue II. P. 226-227.

9. Waelde Thomas and James Gundersson, Legislative Reform in Transition Economies: Western Transplants - a Short-cut to Social Market Economy Status? 43 ICLQ, 1994. P. 347- 378.

10. Mattei U. Comparative law and economics. P. 121.

11. Siems Mathias, Malicious legal transplants, Legal Studies, 38, 2008. P. 103-119.

12. Caterina R. Comparative law and economics / Elgar encyclopedia of comparative law / Ed. by J. M. Smits. - Cheltenham: Edward Elgar Publishing Limited, 2006. P. 162.

13. Orucu E. A theoretical framework for transfrontier mobility of law / Transfrontier mobility of law / Ed. by R. Jagtenberg, E. Orucu, A..J. de Roo. The Hague: Kluwer Law International, 1995. P. 5.
14. Orucu E. Critical Comparative Law Considering Paradoxes for Legal Systems in Transition. Deventer: Kluwer, Nederlandse Vereniging voor Rechtsvergelijking. 1999. № 59. URL: http://www.ejcl. org/41/art41-1.htm

15. Klische Uwe, Comparative Law, Oxford University Press, 2019. 928 p.

16. Mathias Reimann, Reinhard Zimmermann, The Oxford Handbook of Comparative Law, 2019 P. 442-474.

17. Jan M. Smits, Elgar Encyclopedia of Comparative Law, Second Edition, 2012. P. 1000.

18. Сапарова А. Правові запозичення як дискурс інтегративного праворозуміння. Підприємниитво, господарство і право. 2019. № 7. С. 248-253.

19. Оборотов Ю.М. Традиції та новації в правовому розвитку:загальнотеоретичніаспекти:автореф. дис. ... докт. юрид. наук: 12.00.01. Одеса, 2003. С. 18.

20. Charles-Louis de Secondat Montesquieu, De l'esprit des lois (On the Spirit of the Laws), book I, ch. 3, Des lois positives, 1748 .

21. Легран П. Неможливість «правових трансплантантів». Порівняльне правознавство. 2013 № 1-2. C. 46-59.

22. Legrand, Pierre, The Impossibility of Legal Transplants, 4 Maastricht J. Eur. \& Comp. L., 1997. P. 111-124

23. Legrand P. Issues in the translatability of law / Nation, language, and the ethics of translation / Ed. by S. Bermann, M. Wood. Princeton: University Press, 2005. P. 42.

24. Eleanor Cashin Ritaine, Legal Engineering in Comparative Law - An Introduction. P. 9-25.

25. Teubner, Gunther, Legal Irritants: Good Faith in British Law or How Unifying Law Ends Up in New Divergences, 61 (1) Modern Law Review, 1998. P. 11-32.

26. Donaggio A. Limitations of legal transplants and convergence to corporate governance practices in emerging markets: the Brazilian case; in S Boubaker, Corporate Governance in Emerging Markets (Berlin: Springer, 2014). P. 465-484.

27. Осакве К. Размышление о природе сравнительного правоведения: некоторые теоретические вопросы. Журнал зарубежного законодательства и сравнительного правоведения. 2006. № 3. С. 54-71.

28. Чебуранова С.Е. Некоторые теоретические проблемы развития национальных правовых систем в условиях глобализации. Порівняльно-правові дослідження. 2008. № 2. С. 17-19.

29. Ткаченко О.В. Проблема порівняльно-правового неофункціоналізму. Підхід «порівняльне правознавство $\mathrm{i}$ економіка». Держава $i$ право. 2005. Вип. 47. С. $33-41$

30. Дамирли М.А. Сравнительно-правовая наука в Украине: теоретико-методологические традиции (XIX - начало XX вв.) : научно-учебное издание. Одесса: Феникс, 2007. 96 с.

31. Сапарова А. О. Поняття і значення правової трансплантації. Сучасні питання економіки і права. 2011. Вип. 2. С. 127-131.

32. Eva Lein, Ideals and realities : Reflections on Law Reception in Eastern European Private Law , in Eva Lein, Josef Skala, Lukas Heckendorn Urscheler Business Law in Transition, A comparative Perspective on Eastern Europe, 2010. P. 13-26. 
Borrowing in corporate law plays an important role, taking into account the globalization processes that are taking place in the world. The practice of legal borrowings has become much more widespread in recent years. This applies to all countries without exception. International law is one of the most powerful sources of such interactions. The presence of legal borrowing in corporate law in Ukraine is noted by a number of ukrainian scholars. Meanwhile, a thorough analysis was not carried out.

The analysis of legal borrowing is important not only in the aspect of clarifying the relation with the process of harmonization, approximation and unification of law, the possibility of applying standardized legal norms, legal constructions, solving problems that arise in connection with this. The issue of legal borrowing is much broader and has a deeper theoretical and methodological significance. Acknowledging the existence of legal borrowing calls into question one of the principles of the theory of law that it is exclusively the state that determines the content of law, and law is always a product of autonomous development in the middle of the state.

In the article the author analyzes the perspectives of both supporters and skeptics of the concept of legal borrowing. The author notes that the perception of the concept of legal transplants among its supporters is significantly different - from the concept of legal borrowing as freely transplantable legal norms and institutions regardless of regional conditions (Allan, Watson, J. Samuel), to the recognition of legal borrowing taking into account socio-economic conditions in the state of transplants' origin (Otto Kahn Freund, E, Oruku, Matthias Siemms, etc.).

The skepticism of most critics of the idea of legal borrowing is reduced to the impossibility of an identical interpretation due to the different levels of legal consciousness, differences in legal thinking, the inability to achieve identical influence on public relations due to the difference in social and economic development in the states.

The author concludes that legal borrowing is important because it allows to improve the corporate law of Ukraine not just only on the basis of the EU law. The concept of legal transplants allows to take into account the experience of applying foreign legal institutions that have proved its effectiveness both in the country of origin and abroad.

Key words: legal borrowing, legal transplant, reception, unification, corporate law, comparative law. 